\title{
Parathyroid hormone related protein in oral squamous cell carcinomas invading the mandible
}

\author{
F P Dunne, S J Bowden, J S Brown, W A Ratcliffe, R M Browne
}

\begin{abstract}
Aim-To assess parathyroid hormone related protein (PTHrP) as a candidate biochemical marker of invasion of the mandible by oral squamous cell carcinoma.

Methods-Tumour PTHrP concentrations were quantitated by immunoassay, and PTHrP was detected by immunohistochemistry, in a cohort of 24 primary squamous cell carcinomas of the mandible.

Results-PTHrP was identified in all tumours examined, but no correlation was found between scores of the intensity and or consistency of staining or tumour PTHrP concentrations and the histological classification of tumour invasion. Conclusion-Although PTHrP was present in all squamous tumours studied, there was no correlation between PTHrP expression and pattern of tumour invasion. However, tumour derived PTHrP may act locally to influence tumour growth and differentiation and resorption of bone. (f Clin Pathol 1995;48:300-303)
\end{abstract}

Keywords: Squamous cell carcinomas, parathyroid hormone related protein.

In normal adult bone there is a continuous but slow process of remodelling involving osteoclastic resorption and osteoblastic new bone formation. These processes mainly involve the endosteal bone surfaces with much more limited change occurring on the periosteal aspect. The invasion of bone by tumour may be associated with an increase in both osteoclastic and osteoblastic activity. Before invasion of the mandible, squamous cell carcinomas in close proximity to bone initially induce deposition of new bone, especially on the periosteal surface. In the early stages of tumour invasion the haemopoietic marrow is replaced by fibrous tissue and as tumour invasion continues so does the fibrosis of the marrow and osteoclastic resorption. Deposition of new bone can also occur in uninvaded parts of the mandible, possibly as a local response to the presence of squamous cell carcinoma in soft tissues. ${ }^{1}$ Two distinct types of invasion of the mandible by oral squamous cell carcinomas have been described..$^{2-4}$ In the arrosive pattern the tumour advances on a broad front separated from bone by a layer of connective tissue and osteoclasts are present in the region between bone and connective tissue. By contrast, the invasive pat- tern is associated with fingers and islands of tumour tissue which invade cancellous spaces with no intervening layer of connective tissue and little osteoclastic activity. Both types of invasion have been reported to occur concurrently in the same specimen, the arrosive pattern tending to precede and develop into an invasive lesion. In addition, the greater the tumour burden in the involved bone the more likely the pattern of infiltration is invasive in type (personal communication, 1994, Brown and Browne).

At present, preoperative imaging is unreliable and there are no reliable tumour markers to distinguish these different types of tumour invasion. Such information would enable the surgeon to more accurately determine the extent of mandibular resection required for effective treatment. In seeking a new biochemical marker for invasion of the mandible by squamous cell carcinomas, we have studied parathyroid hormone related protein (PTHrP).

PTHrP is a tumour derived calciotropic hormone, first isolated in $1987 .{ }^{56}$ It shares sequence homology with parathyroid hormone (PTH) at the amino terminus where eight of the first 13 amino acids are identical, ${ }^{7}$ enabling PTHrP to mimic the actions of PTH on bone by interacting with PTH receptors. ${ }^{8}$ The role of PTHrP as the primary humoral factor responsible for bone resorption in the syndrome of humoral hypercalcaemia of malignancy (HHM) is now firmly established. There is high frequency of expression of both PTHrP messenger RNA (mRNA) and peptide in squamous cell tumours irrespective of the calcium status of the patient. ${ }^{9}$ In addition, PTHrP has growth factor activity, ${ }^{10-12}$ and recent studies have found a positive correlation between production of PTHrP by tumours and the degree of tumour invasion. ${ }^{1314}$

The aim of this study was to examine the expression of PTHrP in a cohort of 24 primary squamous cell carcinomas of the oral mucosa invading the mandible and to compare the pattern of tumour invasion with the expression of the peptide in tumours, quantitated by immunoassay and detected by immunohistochemistry.

\section{Methods}

Twenty four patients with primary oral squamous cell carcinomas associated clinically with invasion of the mandible were included in the study. All were normocalcaemic at the time of surgery. The tumours were classified into four histological groups according to the pattern 
of invasion as follows: seven invasive, seven arrosive, four mixed pattern, and six non-invasive. The degree of differentiation was classified according to a simple three point scale (poorly differentiated, moderately well differentiated, or well differentiated).

Tumour tissue for immunohistochemistry obtained at the time of operation was fixed in formalin and embedded in paraffin wax. Representative paraffin wax blocks were selected from each case and $5 \mu \mathrm{m}$ sections cut. Tissue portions of eight tumours $(0 \cdot 2-1 \cdot 0 \mathrm{~g})$ were sliced finely and immediately frozen in liquid nitrogen or dry ice and stored at $-70^{\circ} \mathrm{C}$ for later extraction and quantitation of PTHrP by immunoassay. Blood for assay of plasma PTHrP 1-86 was collected preoperatively with lithium heparin as the anticoagulant, separated within 15 minutes, and the plasma stored frozen until assay.

Immunohistochemistry was performed on tumour tissue using a method described previously. ${ }^{10}$ Endogenous peroxidase activity was blocked by treatment of sections with hydrogen peroxide, periodic acid and finally potassium borohydride. The primary rabbit antiserum (code 3592, bleed 6) to PTHrP 37-67 was applied at a dilution of 1 in 200 for 30 minutes at room temperature. This antiserum is specific for residues 51-62 and shows no significant cross-reactivity with PTH or other sub-fragments of PTHrP . ${ }^{15}$ The second antibody was a peroxidase conjugated sheep antirabbit immunoglobulin (The Binding Site, Birmingham, UK) applied at a dilution of 1 in 100. Peroxidase was localised with diaminobenzidine $(2.5 \mathrm{mg} / \mathrm{ml})$ and hydrogen peroxide $0.3 \%(\mathrm{v} / \mathrm{v})$ in phosphate buffer, and nuclei counterstained with Mayer's haematoxylin. Two consecutive sections of each tumour were stained and each batch included known positive and negative controls. In addition, the primary antibody was omitted or replaced with non-immune rabbit serum, or the primary antibody was preincubated with PTHrP 37-67 $(0 \cdot 4 \mathrm{~g} / \mathrm{l})$ for 24 hours at $4^{\circ} \mathrm{C}$. Staining of tumours was assessed by an independent observer.
Interpretation of the staining was based on the technique of Nadji and Morales. ${ }^{16}$ The consistency of staining was scored as follows: $(+)=<10 \%,(++)=10-50 \%,(+++)=50-$ $70 \%,(++++)=>70 \%$. The intensity of brown staining was also graded in relation to that of a positive lung tumour control which was used throughout: $(+)=$ very light, $(++)=$ moderate, $(+++)=$ very dark.

Tissue was extracted by homogenisation in 10 volumes of $1 \mathrm{M}$ acetic acid as previously described. ${ }^{17}$ After one hour of incubation on ice, the homogenate was centrifuged at $13000 \times g$ for five minutes and the supernatant fluid was frozen, lyophilised and reconstituted in assay diluent for quantitation of PTHrP by immunoassay.

PTHrP 1-86 immunoreactivity in lyophilised tumour extracts $(1 \mathrm{ml})$ and column fractions $(0.53 \mathrm{ml})$ reconstituted in assay buffer, phosphate buffered saline ((PBS), $\mathrm{pH}$ $7 \cdot 4$, containing $0.25 \%$ Polypep, $0.1 \%$ Triton $\times 100$ and $0.01 \%$ sodium azide) was measured by a validated two-site immunoradiometric assay (IRMA). ${ }^{16}$ The assay is specific for residues 17-61 of PTHrP and the detection limit of the assay is $0.23 \mathrm{pmol} / 1$. Tissue extracts were diluted serially for assay (for example, 1 in 5 to 1 in 160). The protein content of reconstituted tumour extracts was determined by a protein microassay (BioRad).

Gel filtration chromatography was performed as previously described. ${ }^{18}$ Tissue extract, reconstituted in $1 \mathrm{ml}$ assay diluent, was applied to a Bio-Gel P100 column $(100 \times 1 \mathrm{~cm})$ equilibrated in $1 \mathrm{M}$ acetic acid. Fractions of $0.53 \mathrm{ml}$ were collected, lypohilised and reconstituted in assay diluent for quantitation of PTHrP 1-86 activity. The column was calibrated with the following protein standards and iodinated PTHrP peptides: bovine serum albumin, $66 \mathrm{kDa}$; carbonic anhydrase, $29 \mathrm{kDa}$; ${ }^{125} \mathrm{I}-\mathrm{PTHrP} \quad 1-141,16 \mathrm{kDa}$; cytochrome c, $12.4 \mathrm{kDa} ;{ }^{125} \mathrm{I}-\mathrm{PTHrP} \quad 1-86,9.9 \mathrm{kDa}$; aprotinin, $6.5 \mathrm{kDa}$; and ${ }^{125} \mathrm{I}-\left(\mathrm{Tyr}^{0}\right)-\mathrm{PTHrP}-34$, $4 \cdot 1 \mathrm{kDa}$.

Table 1 Histology and immunohistochemical detection of PTHrP in tumours invading the mandible

\begin{tabular}{|c|c|c|c|c|c|}
\hline \multirow[b]{2}{*}{ Patient No. } & \multirow[b]{2}{*}{ Invasion } & \multirow[b]{2}{*}{ Degree of differentiation } & \multicolumn{2}{|c|}{ Immunohistochemistry } & \multirow[b]{2}{*}{ Site of tumour } \\
\hline & & & Intensity & Consistency & \\
\hline 1 & Invasive & Moderate & +++ & + & Alveolar \\
\hline 2 & Invasive & Moderate & & + & Retromolar \\
\hline 3 & Invasive & Poor & ++ & +++ & Unknown \\
\hline 4 & Invasive & Well & ++ & ++ & Retromolar \\
\hline 5 & Invasive & Moderate & ++ & ++ & Retromolar \\
\hline 6 & Invasive & Moderate & $+t$ & ++ & Alveolar \\
\hline 7 & Invasive & Moderate & $++t$ & $++t$ & Retromolar \\
\hline 8 & Arrosive & Moderate & $++t$ & ++ & Floor of mouth \\
\hline 9 & Arrosive & Moderate & + & + & Buccal mucosa \\
\hline 10 & Arrosive & NA & $t+t$ & $++t+$ & Retromolar \\
\hline 11 & Arrosive & Well & ++ & ++ & Retromolar \\
\hline 12 & Arrosive & Well & +++ & ++ & Alveolar \\
\hline 13 & Arrosive & Moderate & ++ & $++t$ & Retromolar \\
\hline 14 & Arrosive & Moderate & ++ & ++ & Submental \\
\hline 15 & Mixed & Moderate & ++ & +++ & Floor of mouth \\
\hline 16 & Mixed & Well & ++ & ++ & Alveolar \\
\hline 17 & Mixed & Moderate & +++ & $++t$ & Alveolar \\
\hline 18 & Mixed & Well & ++ & ++ & Retromolar \\
\hline 19 & Non-invasive & Well & ++ & ++ & Floor of mouth \\
\hline 20 & Non-invasive & Well & ++ & ++ & Retromolar \\
\hline 21 & Non-invasive & Well & ++ & ++ & Floor of mouth \\
\hline 22 & Non-invasive & Well & ++ & $++t$ & Floor of mouth \\
\hline 23 & Non-invasive & Moderate & ++ & ++ & Floor of mouth \\
\hline 24 & Non-invasive & Moderate & + & + & Tongue \\
\hline
\end{tabular}

NA, not available. 


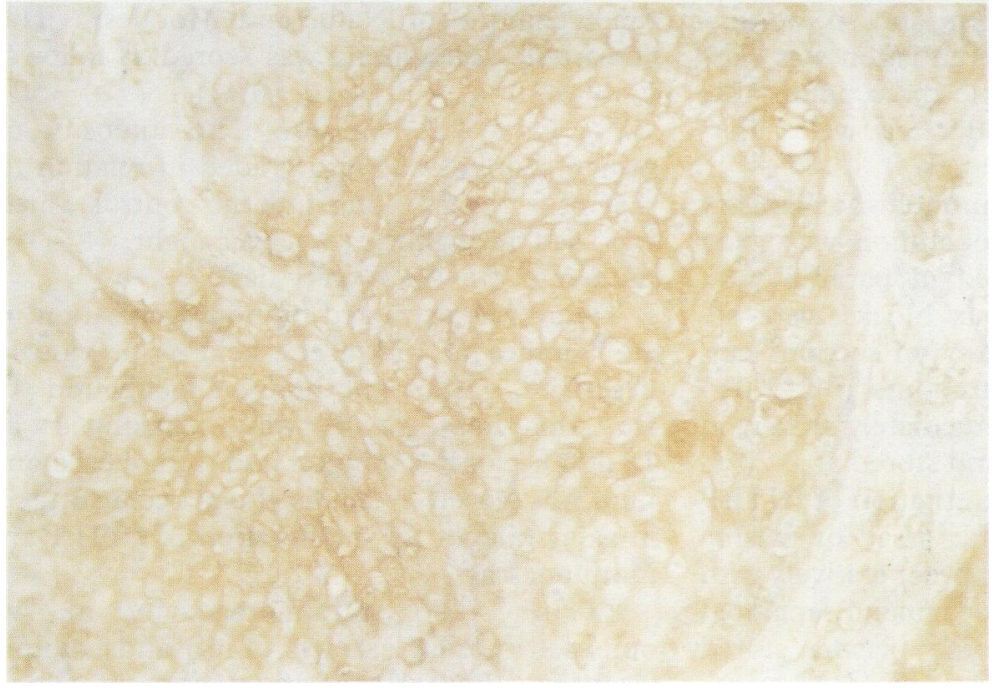

Figure 1 Positive immunostaining for PTHrP in an oral squamous cell carcinoma invading the mandible.
Table 2 Concentration of PTHrP in oral squamous cell carcinomas

\begin{tabular}{lcc}
\hline Patient No. & $\begin{array}{l}\text { PTHrP 1-86 } \\
\text { immunoreactivity } \\
\text { (fmol/g wet weight) }\end{array}$ & $\begin{array}{l}\text { Immunoreactivity } \\
\text { (pmol/g protein) }\end{array}$ \\
\hline 5 & 48 & 13 \\
6 & 3869 & 1517 \\
7 & 218 & 52 \\
12 & 1650 & 351 \\
14 & 1716 & 5361 \\
18 & 1105 & 363 \\
23 & 3898 & 555 \\
24 & 2430 & 2847 \\
Median & 1683 & 459 \\
\hline
\end{tabular}

Immunoreactive PTHrP 1-86 was quantified by a two-site immunoradiometric assay and expressed in terms of the wet weight of the tissue and protein content of the tissue extract.

tions treated with non-immune serum or preabsorbed PTHrP antibody were negative. Immunohistochemical staining did not correlate with the pattern of invasion. There were no significant correlations between the intensity and/or consistency of staining for PTHrP and the invasiveness or degree of differentiation of the tumour (table 1).

Tumour concentrations of PTHrP are shown in table 2. In all cases PTHrP was extracted from tumours diluted in parallel to the standard in the immunoassay. PTHrP 1-86 activity was detected in all eight tumours examined, although no concordance was found between the concentrations measured and the intensity or consistency of staining by immunohistochemistry. Tumour PTHrP concentrations were in the range 48-3898 fmol/g tissue (median $1683 \mathrm{fmol} / \mathrm{g}$ tissue) and $13-5361 \mathrm{pmol} / \mathrm{g}$ protein (median $459 \mathrm{pmol} / \mathrm{g}$ protein) (table 2 ).

In order to further characterise the PTHrP immunoreactivity present in tumours, gel filtration chromatography was performed on three tumour extracts and 1-86 immunoreactivity was measured in the resulting column fractions. Elution profiles are shown in fig 2. The major component eluted at approximately $30 \mathrm{kDa}$ and there was also evidence of a second component eluting at approximately $20 \mathrm{kDa}$. ing $(+)$ (table 1$)$. The pattern of staining was cytoplasmic and homogeneous and parallel sec-

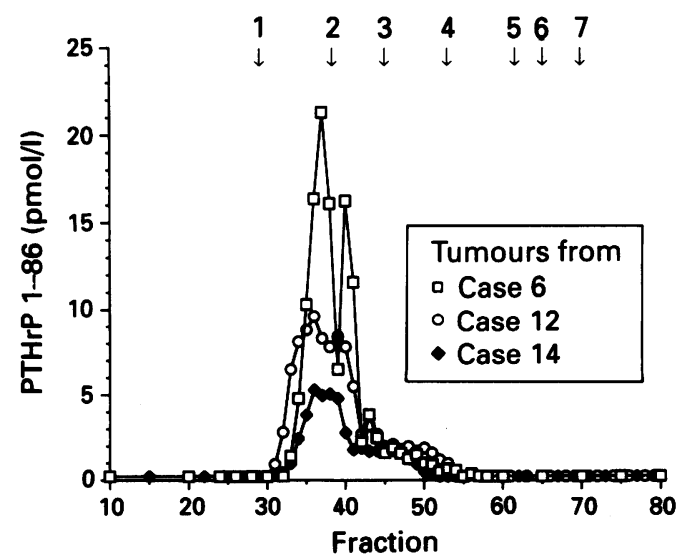

Figure 2 Elution profile of PTHrP extracted from a squamous cell carcinoma invading the mandible. Chromatographic separation of PTHrP 1-86 immunoreactivity was performed on a Bio-gel P100 column in $1 M$ acetic acid. The column was calibrated with (1) bovine serum albumin; (2) carbonic anhydrase; (3) ${ }^{125} I-P T H r P ~ 1-141$; (4) cytochrome $C$; (5) ${ }^{125} I-$ PTHrP 1-86; (6) aprotinin; (7) ${ }^{125}$ I-PTHrP 1-34.

\section{Discussion}

PTHrP was identified by immunohistochemistry in all 24 squamous cell tumours of the mandible. Similar high frequencies of expression have previously been found in various tumours of squamous cell type from both normocalcaemic and hypercalcaemic patients. ${ }^{91920}$ In the majority of tumours of the mandible studied, staining was cytoplasmic, and scores of intensity and/or consistency of staining were unrelated to the histological pattern of tumour invasion.

PTHrP 1-86 concentrations quantified in the tumour extracts (range 48-3898 fmol/g tissue) were within the range previously found in other tumours from normocalcaemic and hypercalcaemic patients $(<4-4630 \mathrm{fmol} / \mathrm{g}$ tissue) ${ }^{17}$ and there was no evidence to suggest that PTHrP concentrations in the tumours correlated with tumour invasion nor did tumour concentrations of PTHrP correlate 
with immunostaining scored for intensity and/ or consistency. This may reflect differences in the specificities of these techniques since the IRMA recognises residues 17-61, while immunohistochemistry detects peptides containing residues $49-61$. The molar excess of mid-region fragments of PTHrP relative to PTHrP 1-86 described in normal and tumour tissue could also account for this discrepancy. ${ }^{21}$

Characterisation of tumour PTHrP by gel filtration chromatography resolved a major species of $30 \mathrm{kDa}$, together with species of lower molecular weight eluting at $20 \mathrm{kDa}$. Similar molecular heterogeneity has been previously found in PTHrP extracted from both malignant and non-malignant tissue ${ }^{1722}$ and is assumed to reflect native isoform(s) of PTHrP together with amino-terminal sub-fragments derived by proteolytic processing in tumours at site(s) in the carboxyl-terminus of the peptide. ${ }^{23}$

There is accumulating evidence to support the local actions of PTHrP in malignant and normal tissues. PTHrP has growth factor-like properties in fibroblasts, ${ }^{11}$ osteoblasts ${ }^{10}$ and embryonal carcinoma cells, ${ }^{12}$ and the presence of high capacity, low affinity binding sites for PTHrP in squamous carcinoma cell lines ${ }^{24}$ has suggested that these actions are locally mediated. In a human keratinocyte cell line there was evidence that endogenous PTHrP acted as an inhibitor of cell growth ${ }^{25}$ while progressive dysregulation of PTHrP expression and secretion occurred in keratinocytes undergoing transformation to a malignant phenotype. ${ }^{26}$ The malignant transformation associated with cell dedifferentiation may lead to changes in the rate of transcription of the PTHrP gene, such as occurs when there is interaction between fibroblasts and tumour cells during tumour invasion. ${ }^{27}$ In breast cancer expression of PTHrP in the primary tumour may be linked to the spread of the tumour to bone rather than non-bone sites. ${ }^{28}$

In conclusion, although PTHrP peptide was present in all oral squamous cell carcinomas studied, the intensity and/or consistency of staining was unrelated to the pattern of tumour invasion. However, it is possible that tumour derived PTHrP may act locally to influence growth and dedifferentiation and resorption of bone.

We thank the Department of Health (WAR and SJB) and the Wellcome Trust (FPD) for financial support.

1 McGregor AD, MacDonald GD. Reactive changes in the mandible in the presence of squamous cell carcinoma. Head Neck 1988;10:378-86.

2 Schwartz S, Shklar G. Reaction of alveolar bone to invasion of oral carcinoma. Oral Surg Oral Med Oral Pathol 1967; 24:33-7.

3 Slootweg PJ, Muller H. Mandibular invasion by oral squamous cell carcinoma. F Craniomaxillofac Surg 1989;17:6974.

4 Lukinmaa PL, Hietanen AL, Soderholm C, Lindquist C. The histologic pattern of bone invasion by squamous cell carcinoma of the mandibular region. Br f Oral Maxillofac Surg 1992;30:2-7.

5 Mangin M, Webb A, Dreyer B, Posillico J, Ikeda K, Weir $\mathrm{E}$, et al. Identification of a cDNA encoding a parathyroid hormone-like peptide from a human tumor associated with humoral hypercalcemia of malignancy. Proc Natl Acad Sci USA 1988;85:597-601.

6 Suva LJ, Mather KA, Gillespie MT, Webb GC, Ng KW, Winslow GA, et al. Structure of the $5^{\prime}$ flanking region of the gene encoding human parathyroid hormone-related protein (PTHrP). Gene 1989;77:95-105.

7 Suva LJ, Winslow GA, Wettenhall REH, Hammonds RG, Moseley JM, Dieffenbach-Jagger $\mathrm{H}$, et al. A parathyroid hormone-related protein implicated in malignant hypercalcemia: cloning and expression. Science 1987;237: percalcemi

8 Juppner $\mathrm{H}$, Abou-Samra A, Uneuo S, Gu W, Potts JT, Segre JV. The parathyroid hormone-like peptide associated with humoral hypercalcemia of malignancy and parathyroid hormone bind to the same receptor on the plasma membrane of ROS $17 / 2 \cdot 8$ cells. F Biol Chem 1988;263: 8557-60.

9 Dunne FP, Lee S, Ratcliffe WA, Hutchesson AC, Bundred NJ, Heath DA. Parathyroid hormone-related protein (PTHrP) gene expression in solid tumours associated with normocalcaemia and hypercalcaemia. $\mathcal{f}$ Pathol 1993;171: 215-21

10 Centrella M, Canalis E, McCarthy TL, Stewart AF, Orloff $\mathrm{JJ}$, Insogna KL. Parathyroid hormone-related protein modulates the effect of transforming gowth factor-beta on deoxyribonucleic acid and collagen synthesis in fetal rat bone cells. Endocrinology 1989;125:199-208

11 Insogna KL, Stewart AF, Morris CA, Hough LM, Milstone LM, Centrella $M$. Native and a synthetic analogue of the malignancy-associated parathyroid hormone-like protein have in-vitro transforming growth factor-like properties. $\mathcal{F}$ Clin Invest 1989;83:1057-60.

12 Chan SDH, Strewler GJ, King KL, Nissenson RA. Expression of a parathyroid hormone-like protein and its pression of a parathyroid hormone-like protein and its
receptor during differentiation of embryonal carcinoma receptor during differentiation of em
cells. Mol Endocrinol 1990;4:638-46.

13 Kitazawa S, Kitazawa R, Fukase M, Fujimori T, Maeda S. Immunohistochemical evaluation of parathyroid hormone-related protein (PTHrP) in the uterine cervix. Int f Cancer 1992;50:731-5.

14 Dunne F, Rollason T, Ratcliffe WA, Marshall T. Parathyroid hormone related protein (PTHrP) gene expression in invasive cervical tumours. Cancer 1994;74:83-9.

15 Ratcliffe WA, Norbury S, Heath DA, Ratcliffe JG. Development and validation of an immunoradiometric assay of parathyrin-related protein in unextracted plasma. Clin Chem 1991;37:678-85.

16 Nadji M, Morales AR. Immunoperoxidase techniques: a practical approach to tumour diagnosis. Chicago, Chicago Press: American Society of Clinical Pathologists, 1986.

17 Bowden SJ, Hughes SV, Ratcliffe WA. Molecular forms of parathyroid hormone-related protein in tumours and biological fluids. Clin Endocrinol 1993;38:287-94.

18 Payne CD. The GLIM System Release 3.77. Generalised Linear Interactive Modelling. Oxford: Numerical Algorithms Group Ltd, 1985.

19 Danks JA, Ebeling PR, Hayman J. Parathyroid hormonerelated protein of cancer: immunohistochemical localisation in cancers and in normal skin. F Bone Mineral Res 1989;4:273-8.

20 Ralston SH, Danks JA, Hayman J, Fraser WD, Stewart CS, Martin TJ. Parathyroid hormone-related protein of CS, Martin TJ. Parathyroid hormone-related protein of malignancy: immunohistochemical and biochemical stud-
ies in normocalcaemic and hypercalcaemic patients with cancer. F Clin Pathol 1991;44:472-6.

21 Ratcliffe WA, Bowden SJ, Dunne FP, Hughes S, Emly JF, Baker JT, et al. Expression and processing of parathyroid hormone-related protein in a pancreatic endocrine cell tumour associated with hypercalcaemia. Clin Endocrinol 1994;40:679-86.

22 Bowden SJ, Emly JF, Hughes SV, Powell G, Ahmed A, Whittle MJ, et al. Parathyroid hormone-related protein in human term placenta and membranes. $\mathcal{F}$ Endocrinol 1994; 142:217-24.

23 Orloff JJ, Reddy D, Depapp AE, Yang KH, Soifer NE, Stewart AF. Parathyroid hormone-related protein as a prohormone-posttranslational processing and receptor interactions. Endocrine Rev 1994;15:40-60.

24 Orloff JJ, Ganz MB, Ribaudo AE, Burtis WJ, Reiss M, Milstone LM, et al. Analysis of PTHrP binding and signal transduction mechanisms in benign and malignant squamous cells. Am $\mathcal{f}$ Physiol 1992;262:E599-607.

25 Kaiser SM, Laneuville P, Bernier SM, Rhim JS, Kremer R, Goltzman D. Enhanced growth of a human keratinocyte cell line induced by antisense RNA for parathyroid hor mone-related peptide. $\mathcal{F}$ Biol Chem 1992;267:13623-8.

26 Henderson J, Sebag M, Rhim J, Goltzman D, Kremer R. Dysregulation of parathyroid hormone-like peptide expression and secretion in a keratinocyte model of tumour expression and secretion in a keratinocyte

27 Lowik C, Hoekman K, Offringa R, Groot C, Hendy G, Papapoulos E, et al. Regulation of parathyroid hormonelike protein production in cultured normal and malignan keratinocytes. F Invest Dermatol 1992;98:198-203.

28 Powell GJ, Southby J, Danks JA, Stillwell RG, Hayman JA, Henderson MA, et al. Localisation of parathyroid hormone-related protein in breast cancer metastases: increased incidence in bone compared with other sites. Cancer Res 1991;51:3059-61. 